\title{
Brake torque of a diesel engine fuelled with biodiesel and diesel
}

\author{
Alireza Shirneshan \\ Department of Mechanical Engineering, Najafabad Branch, Islamic Azad University, Isfahan, Iran
}

Email address:

arshirneshan@yahoo.com

\section{To cite this article:}

Alireza Shirneshan. Brake Torque of a Diesel Engine Fuelled with Biodiesel and Diesel. International Journal of Renewable and Sustainable Energy. Vol. 2, No. 6, 2013, pp. 242-246. doi: 10.11648/j.ijrse.20130206.18

\begin{abstract}
Brake torque of a diesel engine was investigated by considering the effects of biodiesel (from waste cooking oil) in fuel mixture (biodiesel and diesel fuel) on this performance characteristic. The experiments were done on a 4 cylinder direct-injection diesel engine. Results showed that by the use of biodiesel brake power decreases up to $17 \%$. Also results showed that the increase in engine load appeared to cause an increase in the brake power up to $69 \%$. On the other hand by increasing rpm of the engine brake power increases continuously up to speed 1800 to $2000 \mathrm{rpm}$ and after that drops.
\end{abstract}

Keywords: Brake Torque, Biodiesel, Diesel, Engine

\section{Introduction}

As a renewable, sustainable and alternative fuel for compression ignition engines, biodiesel instead of diesel has been increasingly fueled to study its effects on engine performances and emissions in the recent 10 years.

The resources of petroleum as fuel are dwindling day by day and increasing demand of fuels, as well as increasingly stringent regulations, pose a challenge to science and technology.

With the commercialization of bio energy, it has provided an effective way to fight against the problem of petroleum scarce and the influence on environment.

Bio fuels such as alcohols and biodiesel have been proposed as alternatives for diesel engines (Agarwal, 2007; Demirbas, 2007; Ribeiro et al., 2007). The fuel properties of biodiesel may be changed when different feedstocks are used. If the fuel properties of biodiesel are compared to petroleum diesel fuel, it can be seen that biodiesel has higher viscosity, density, pour point, flash point and cetane number, near-zero aromatic compound, and no sulphur link (Canakci and Ozsezen, 2005; Knothe, 1997).

In particular, biodiesel has received wide attention as a replacement for diesel fuel because it is biodegradable, nontoxic and can significantly reduce toxic emissions and overall life cycle emission of $\mathrm{CO} 2$ from the engine when burned as a fuel (Cvengroš and Považanec, 1996; USEPA, 2002). Biodiesel can form blends with petroleum diesel fuel at any ratio and thus have the potential to partially, or even totally, replace diesel fuel in diesel engines.

Biodiesel fuel has many effects on diesel engine performance. There has been a lot of research on the regulated performance characteristics of diesel engines with biodiesel/diesel blends.

Biodiesel can be produced from various vegetable oils, waste cooking oils and animal fats. The fuel properties of biodiesel may be changed when different feedstocks are used. If the fuel properties of biodiesel are compared to petroleum diesel fuel, it can be seen that biodiesel has higher viscosity, density, pour point, flash point and cetane number, near-zero aromatic compound, and no sulphur link (Canakci and Ozsezen, 2005; Knothe, 1997).

In particular, biodiesel has received wide attention as a replacement for diesel fuel because it is biodegradable, nontoxic and can significantly reduce toxic emissions and overall life cycle emission of $\mathrm{CO} 2$ from the engine when burned as a fuel (Cvengroš and Považanec, 1996; USEPA, 2002). Biodiesel can form blends with petroleum diesel fuel at any ratio and thus have the potential to partially, or even totally, replace diesel fuel in diesel engines.

Biodiesel fuel has many effects on diesel engine performance. There has been a lot of research on the regulated performance characteristics of diesel engines with biodiesel/diesel blends.

There are many literatures to study the effect of pure biodiesel on engine torque, and most of them agreed that, 
with biodiesel (especially with pure biodiesel), engine torque will drop (Utlua and Kocak, 2008; Aydin and Bayindir, 2010; Hazar, 2009; Ozsezen et al., 2009; Karabektas, 2009; Xue et al., 2011; Keskin et al., 2008). However, the results reported show some fluctuation. Utlu and Kocak (2008) found that the respective average decrease of torque values of WFOME (waste frying oil methyl ester) was $4.3 \%$ and $4.5 \%$. Hansen et al. (2006) observed that the brake torque loss was $9.1 \%$ for B100 biodiesel relative to D2 diesel at 1900rpm.

Murillo et al. (2007) found that the loss of torque was $7.14 \%$ for biodiesel compared to diesel on a 3-cylinder, naturally aspirated (NA), submarine diesel engine at full load. Yücesu and Cumali (2006) found that the torque and power reduced by $3-6 \%$ for pure cotton seeds biodiesel compared to diesel.

It was reported that there was no significant difference in engine torque and power between pure biodiesel and diesel (Lin et al., 2009; Qi et al., 2009). For instance, Lin et al.(2009) found that the maximum and minimum differences in engine torque and power at full load between PD (petroleum diesel) and 8 kinds of VOME (vegetable oil methyl ester) fuels were only $1.49 \%$ and $-0.64 \%, 1.39 \%$ and $-1.25 \%$, respectively. And Qi et al. (2009) reported this trend.

Of course, it was reported that there were surprising increases in torque of engine for pure biodiesel (Song and Zhang, 2008; Al-Widyan et al., 2002). Song and Zhang (2008) observed that the engine brake torque increased with the increase in biodiesel percentage in the blends. But it is the most unbelievable that the increased torque of the pure biodiesel could reach $70 \%$ relative to diesel fuel (AlWidyan et al., 2002).

Although the basic trends of engine torque performance with load or speed were similar for biodiesel engine and diesel engine, there existed offset of maximum value of torque for biodiesel compared to diesel (Aydin and Bayindir, 2010; Gumus and Kasifoglu, 2010).

Hossain et al. (2012) investigated full engine power with both blends, and very little difference in engine performance results were observed between $20 \%$ and $30 \%$ blends. At full engine load, the brake specific fuel consumption on a volume basis was around $6 \%$ higher for the blends when compared to fossil diesel.

The brakes thermal efficiencies were about 3-6\% lower than biodiesel and were similar to fossil diesel. The study concludes that up to $20 \%$ blend of de-inking sludge pyrolysis oil with biodiesel can be used in an indirect injection $\mathrm{CI}$ engine without adding any ignition additives or surfactants.

Palm fatty acid distillate that is a waste from extraction of palm oil. PFAD is used by Malvade et al. (2013) for production of biodiesel. A single cylinder water cooled diesel engine was used for evaluating performance of PFAD biodiesel blends and diesel.

The engine performance for various PFAD biodiesel blends at various loads was comparatively equal to that of diesel fuel. Brake power of various blends is comparatively equal to brake power of diesel. Brake Thermal Efficiency increases comparatively for 50\% PFAD blends. Specific Fuel Consumption for PFAD blends is slightly higher than diesel. Indicated power of PFAD blends is less than indicated power of diesel.

The biodiesel diesel blends $(10 \%, 20 \%, 30 \%$ and $50 \%)$ were used by Silitonga et al. (2013) to conduct engine performance and exhaust emission characteristic at different engine speeds. The experimental results showed that CPB10 blend give the best results on engine performance such as engine torque and power at $1900 \mathrm{rpm}$ with full throttle condition. Besides, the brake specific fuel consumption at maximum torque $(161 \mathrm{~g} / \mathrm{kW} \mathrm{h})$ for CPB10 is higher about $22.98 \%$ relative to diesel fuel $(198 \mathrm{~g} / \mathrm{kW} \mathrm{h})$. This is shown that the lower biodiesel diesel blends ratio will increase the performance and reduce the fuel consumption.

Koc et al. (2013) investigated the effects of water concentration in a biodiesel nanoemulsion fuel on engine performance and exhaust emissions of a diesel engine. Biodiesel nanoemulsions containing 5\%, 10\% and 15\% water were used for the engine tests and the results were compared with B5, B20 and certified diesel fuels.

Biodiesel nanoemulsion with $5 \%$ water concentration produced engine power and torque values that were similar to the values measured for B5 fuel.

Emulsified biodiesel fuel is a promising alternative method for reducing harmful emissions from diesel engines without requiring significant engine modifications.

Yamin et al. (2013) presented a comparative study on the use of new as well as waste oil as source for biodiesel fuel for compression ignition engine. The engine performance and emission characteristics were studied and compared with pure diesel fuel.

The results showed that there was a loss in the fuel calorific value of about $13.43 \%$ for waste oil biodiesel and $7.24 \%$ for unused oil biodiesel. Further, the density of the fuel was found to increase by about $4.75 \%$ with respect to pure reference fuel. As for the performance, biodiesel showed improvement in the torque, power and thermal efficiency and reduction in the specific fuel consumption. This was achieved both as full and low load.

Liaquat et al. (2013) investigated the engine performance parameters and emissions characteristics for direct injection diesel engine using coconut biodiesel blends without any engine modifications.

A total of three fuel samples, such as DF $(100 \%$ diesel fuel), CB5 (5\% coconut biodiesel and 95\% DF), and CB15 $(15 \% \mathrm{CB}$ and $85 \% \mathrm{DF})$ respectively are used. Engine performance test has been carried out at $100 \%$ load, keeping throttle $100 \%$ wide open with variable speeds of 1500 to $2400 \mathrm{rpm}$ at an interval of $100 \mathrm{rpm}$.

As results of investigations, there has been a decrease in torque and brake power, while increase in specific fuel consumption has been observed for biodiesel blended fuels over the entire speed range compared to net diesel fuel. 
Effect of Karanja biodiesel (Karanja oil methyl ester; KOME) and its blends on engine performance, emissions and combustion characteristics in a direct injection compression ignition (DICI) engine of a medium size utility vehicle with varying engine speed and load has been investigated by Dhar et al. (2014). Maximum torque attained by $10 \%$ and $20 \% \mathrm{KOME}$ blends were higher than mineral diesel, while higher biodiesel blends produced slightly lower torque.

Özener et al. (2014) studied the combustion, performance and emission characteristics of conventional diesel fuel and biodiesel produced from soybean oil and its blends (B10, B20, B50) were compared. The tests were performed at steady-state conditions in a single-cylinder direct injection diesel engine over the entire rpm range (1200-3000 rpm). During the tests, the fuel consumption, pollutant emissions, exhaust temperature and in-cylinder pressures were measured.

The experimental results, showed that, relative to diesel, biodiesel had a $1-4 \%$ decrease in the torque and an approximately $2-9 \%$ increase in the brake-specific fuel consumption (BSFC) due to the lower heating value (LHV) of the biodiesel

The objective of this research work is to investigate the effects of biodiesel percentage of in fuel mixture (biodiesel and diesel fuel No.2) as fuel parameter and engine speed and engine load as engine operation parameters on changes in brake torque of a diesel engine. In addition, using diagrams, the interaction effects of process parameters on the parameters are analyzed and discussed.

\section{Materials and Methods}

\subsection{Biodiesel Preparation and Fuel Properties}

Biodiesel from waste vegetable cooking oil is a more economical source of the fuel, so biodiesel was produced from this source in the present investigation. In the present research, biodiesel was produced by transesterification process TMU biofuels laboratories. The important properties of biodiesel and No. 2 diesel are shown in Table 1.

Table 1. Properties of diesel and biodiesel fuels used for present investigation

\begin{tabular}{|c|c|c|c|c|}
\hline Property & Method & Units & Biodiesel & Diese \\
\hline Flash point & ASTM-D92 & ${ }^{\circ} \mathrm{C}$ & 150 & 61 \\
\hline Pour point & ASTM-D97 & ${ }^{\circ} \mathrm{C}$ & -5 & 0 \\
\hline Cloud point & ASTM-D2500 & ${ }^{\circ} \mathrm{C}$ & -1 & 3 \\
\hline $\begin{array}{l}\text { Kinematical } \\
\text { viscosity, } 40^{\circ} \mathrm{C}\end{array}$ & ASTM-D445 & $\mathrm{mm} 2 / \mathrm{s}$ & 4.3 & 4.15 \\
\hline Density & --------- & $\mathrm{Kg} / \mathrm{m} 3$ & 875 & 830 \\
\hline
\end{tabular}

\subsection{Test Engine Experimental Setup and Procedure}

The engine tests were carried out on a 4-cylinder, fourstroke, turbocharged, water cooled and naturally aspirated DI diesel engine. The engine speed was measured by a digital tachometer with a resolution of $1 \mathrm{rpm}$. The engine was allowed to run for a few times until the exhaust gas temperature, the cooling water temperature, the lubricating oil temperature, have attained steady-state values and then the data were recorded.

\section{Analysis and Results}

\section{Brake torque}

Figures (1 to 4) show the effects of biodiesel percentage and engine speed on the brake torque of the engine at various load condition. As the Figures show the maximum brake torque is more than 334 N.m for fuel blends included less than $15 \%$ biodiesel at full load and engine speed between 1700 to $1900 \mathrm{rpm}$. Also the minimum brake torque (15 N.m) happens at 25\% engine load and $1000 \mathrm{rpm}$ as engine speed for fuel blends included more than $80 \%$ biodiesel.

The values for the brake torques decrease slightly with the increasing amount of biodiesel in the fuel blend. These decreases are understandable, since the heat content of the fuel blend decreases with the increasing amount of biodiesel compared to that diesel fuel No.2 (Aydin and Bayindir, 2010; Hazar, 2009; Ozsezen et al., 2009; Karabektas, 2009; Hansen et al., 2006; Kim and Choi, 2010; Canakci et al., 2009). High lubricity and the higher oxygen content of biodiesel might result in the reduced friction loss and thus improve the brake effective torque and compensates the loss of heating value of biodiesel (Ramadhas et al., 2005).

Figures ( 1 to 4$)$ show the brake torque increases with increasing engine load, because the increase in combustion temperature leads to more complete combustion during the higher load (Xue et al., 2011).

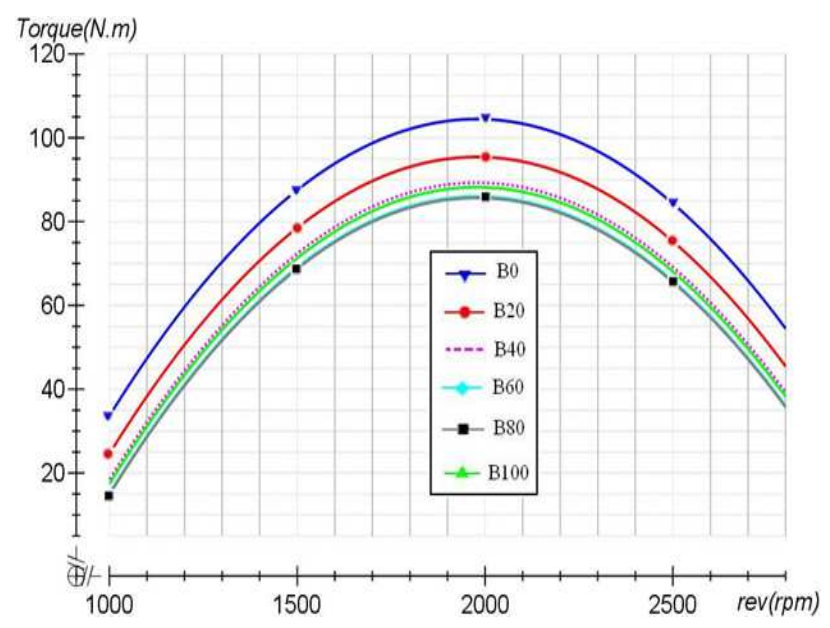

Fig 1. Effect of Percentage of biodiesel in fuel mixture and engine speed on brake torque at $25 \%$ engine load. 


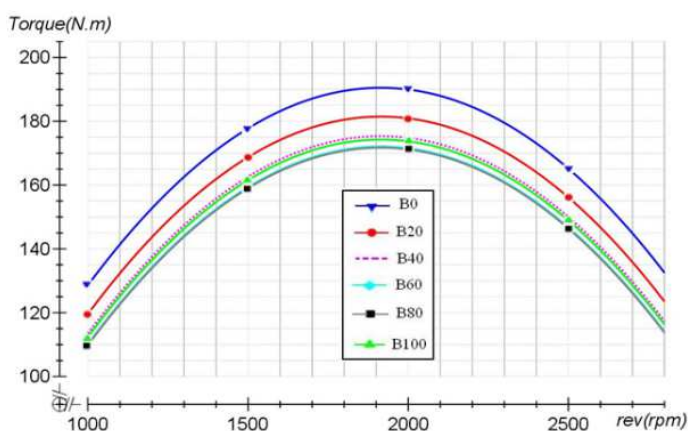

Fig 2. Effect of Percentage of biodiesel in fuel mixture and engine speed on brake torque at $50 \%$ engine load.

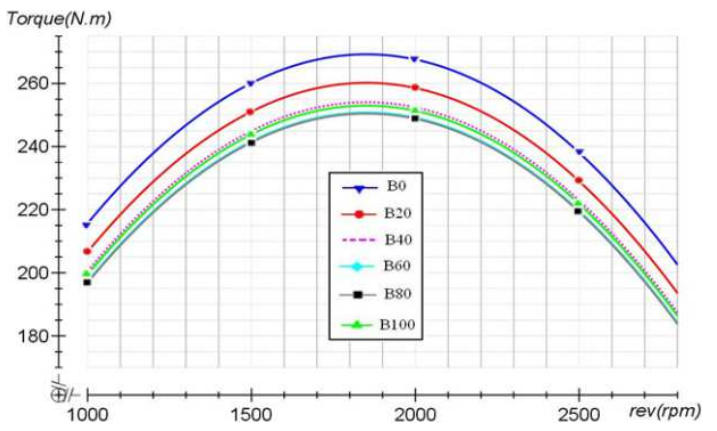

Fig 3. Effect of Percentage of biodiesel in fuel mixture and engine speed on brake torque at $75 \%$ engine load.

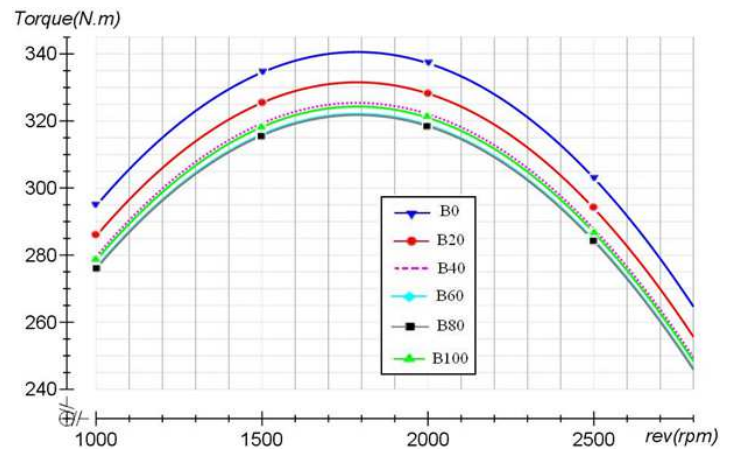

Fig 4. Effect of Percentage of biodiesel in fuel mixture and engine speed on brake torque at full engine load.

\section{Conclusions}

The brake torque decreases with the increase of biodiesel in the blends, due to the lower heating value of biodiesel. Results showed that the brake torque of diesel No.2 fuel is more than $5 \%$ and $17 \%$ more than the brake torque of net biodiesel at full and $25 \%$ engine load respectively.

The increase in engine load appeared to cause an increase in the brake torque up to $68 \%$.

These results are similar to those found in the literature and support that waste cooking oil methyl esters have similar properties with diesel fuel.

By increasing rpm of the engine brake torque increases continuously up to speed 1800 to $2000 \mathrm{rpm}$ and after that drops.

\section{References}

[1] Agarwal A. K. Biofuels (alcohols and biodiesel) applications as fuels for internal combustion engines. Prog Energy Combust Sci 2007; 33:233-71.

[2] Al-Widyan M. I., Tashtoush G, Abu-Qudais M. Utilization of ethyl ester of waste vegetable oils as fuel in diesel engines. Fuel Process Technol 2002; 76:91-103.

[3] Aydin H., Bayindir H. Performance and emission analysis of cottonseed oil methyl ester in a diesel engine. Renew Energ 2010; 35:588-92.

[4] Canakci M., Ozsezen A. N., Arcaklioglu E., Erdil A. Prediction of performance and exhaust emissions of a diesel engine fueled with biodiesel produced from waste frying palm oil. Expert Syst Appl 2009; 36(5):9268-80.

[5] Canakci M., Ozsezen A. N. Evaluating waste cooking oils as alternative diesel fuel. GU J Sci 2005; 18(1):81-91.

[6] Cvengroš J., Považanec F. Production and treatment of rapeseed oil methyl esters as alternative fuels for diesel engines. Bioresour Technol 1996; 55:145-52.

[7] Demirbas A. Progress and recent trends in biofuels. Prog Energy Combust Sci 2007; 33:1-18.

[8] Dhar A., A.K. Agarwal. Performance, emissions and combustion characteristics of Karanja biodiesel in a transportation engine. Fuel, 2014; 119: 70-80.

[9] Gumus M., Kasifoglu S. Performance and emission evaluation of a compression ignition engine using a biodiesel (apricot seed kernel oil methyl ester) and its blends with diesel fuel. Biomass Bioenerg 2010; 34:134-9.

[10] Hazar H. Effects of biodiesel on a low heat loss diesel engine. Renew Energ 2009; 34:1533-7.

[11] Hansen A. C., Gratton M. R., Yuan W. Diesel engine performance and NOx emissions from oxygenated biofuels and blends with diesel fuel. Trans ASABE. 2006; 49:589-95.

[12] Hossain, A. K., Ouadi, M., Siddiqui, S. U., Yang, Y., Brammer, J., Hornung, A., Kay, M., Davies, P. A. Experimental investigation of performance, emission and combustion characteristics of an indirect injection multicylinder CI engine fuelled by blends of de-inking sludge pyrolysis oil with biodiesel. Fuel; 2013, 105:135-142.

[13] Karabektas M. The effects of turbocharger on the performance and exhaust emissions of a diesel engine fuelled with biodiesel. Renew Energy. 2009; 34:989-93.

[14] Keskin A., Gürü M., Altıparmak D. Influence of tall oil biodiesel with $\mathrm{Mg}$ and Mo based fuel additives on diesel engine performance and emission. Bioresource Technol 2008; 99:6434-8.

[15] Koc B. A., Abdullah M. Performance and $\mathrm{NO}_{\mathrm{x}}$ emissions of a diesel engine fueled with biodiesel-diesel-water nanoemulsions. Fuel Processing Technology; Volume 109, May 2013, Pages 70-77.

[16] Liaquat, A.M., H.H. Masjuki, M.A. Kalam, I.M. Rizwanul Fattah, M.A. Hazrat, M. Varman, M. Mofijur, M. Shahabuddin. Effect of Coconut Biodiesel Blended Fuels on Engine Performance and Emission Characteristics. Procedia Engineering. 2013; 56:583-590. 
[17] Murillo S., Miguez J. L., Porteiro J., Granada E., Moran J. C. Performance and exhaust emissions in the use of biodiesel in outboard diesel engines. Fuel 2007; 86:1765-71.

[18] Özener, O., L. Yüksek, A. T. Ergenç., M. Özkan. Effects of soybean biodiesel on a DI diesel engine performance, emission and combustion characteristics. Fuel. 2014;115: $875-883$

[19] Ozsezen A. N., Canakci M., Turkcan A., Sayin C. Performance and combustion characteristics of a DI diesel engine fueled with waste palm oil and canola oil methyl esters. Fuel 2009; 88:629-36.

[20] Qi D. H., Geng L. M., Chen H., Bian Y. Z. H, Liu J., Ren X C. H. Combustion and performance evaluation of a diesel engine fueled with biodiesel produced from soybean crude oil. Renew Energ 2009; 34:2706-13.

[21] Qi D. H., Chen H., Geng, L. M., Bian, Y. Z. H Experimental studies on the combustion characteristics and performance of a direct injection engine fueled with biodiesel/diesel blends. Energ Convers Manage 2010;51:2985-92.

[22] Ribeiro N. M., Pinto A. C., Quintella C. M., Rocha G. O. D. Teixeira L. S. G., Guarieiro L. L. N., et al. The role of additives for diesel and diesel blended (ethanol or biodiesel) fuels: a review. Energ Fuel 2007; 21:2433-45.

[23] Silitonga A.S., H.H. Masjuki, T.M.I. Mahlia, Hwai Chyuan Ong, W.T. Chong. Experimental study on performance and exhaust emissions of a diesel engine fuelled with Ceiba pentandra biodiesel blends. Energy Conversion and Management. 2013, 79:828-836.
[24] Song J-T., Zhang C-H. An experimental study on the performance and exhaust emissions of a diesel engine fuelled with soybean oil methyl ester. P I Mech Eng D-J Aut 2008; 222:2487-96.

[25] USEPA. A comprehensive analysis of biodiesel impacts on exhaust emissions; 2002; EPA420-P-02-001.

[26] Yücesu H. S., Cumali I. Effect of cotton seed oil methyl ester on the performance and exhaust emission of a diesel engine. Energ Source Part A 2006; 28:389-98.

[27] Usta N. An experimental study on performance and exhaust emissions of a diesel engine fuelled with tobacco seed oil methyl ester. Energ Convers Manage 2005; 46:2373-86.

[28] Usta N., Oztürk E., Can O., Conkur E. S., Nas S., Con A. H., et al. Combustion of biodiesel fuel produced from hazelnut soapstock/waste sunflower oil mixture in a diesel engine. Energ Convers Manage 2005;46:741-55.

[29] Utlu Z., Kocak M. S. The effect of biodiesel fuel obtained from waste frying oil on direct injection diesel engine performance and exhaust emissions. Renew Energ 2008; 33:1936-41.

[30] Xue, J., Grift, T. E., Hansen, A. C. Effect of biodiesel on engine performances and emissions. Renewable and Sustainable Energy Reviews. 2011; 15: 1098-1116.

[31] Yamina, J.A. N. Sakhninib, A. Sakhrieha, M.A. Hamdanan. Environmental and performance study of a 4-Stroke CI engine powered with waste oil biodiesel. Sustainable Cities and Society. 9, 2013, 9: 32-38. 